\title{
Erratum: Solving vaccine mysteries: a systems biology perspective
}

Lydie Trautmann \& Rafick-Pierre Sekaly

Nat. Immunol. 12, 729-731 (2011); published online 19 July 2011; corrected after print 10 November 2011

In the version of this article initially published, the volume number for reference 2 was incorrect. The correct volume number is 12 . The error has been corrected in the HTML and PDF versions of the article.

\section{Erratum: Writing a first grant proposal}

Julian Gomez-Cambronero, Lee-Ann H Allen, Martha K Cathcart, Louis B Justement, Elizabeth J Kovacs, Kenneth R McLeish \& William M Nauseef

Nat. Immunol. 13, 105-108 (2011); published online 19 January 2012; corrected after print 3 February 2012

In the version of this article initially published, the first author's surname was incorrect and e-mail address was missing. The correct name is "GomezCambronero"; the e-mail address is julian.cambronero@wright.edu. The error has been corrected in the HTML and PDF versions of the article.

\section{Erratum: SAMHD1 restricts the replication of human immunodeficiency virus type 1 by depleting the intracellular pool of deoxynucleoside triphosphates}

\author{
Hichem Lahouassa, Waaqo Daddacha, Henning Hofmann, Diana Ayinde, Eric C Logue, Loïc Dragin, Nicolin Bloch, Claire Maudet, \\ Matthieu Bertrand, Thomas Gramberg, Gianfranco Pancino, Stéphane Priet, Bruno Canard, Nadine Laguette, Monsef Benkirane, \\ Catherine Transy, Nathaniel R Landau, Baek Kim \& Florence Margottin-Goguet \\ Nat. Immunol. 13, 223-228 (2012); published online 12 February 2012; corrected after print 4 April 2012
}

In the version of this article initially published, the number for Baek Kim's second affiliation is incorrect in the author list. The correct number is 10. The error has been corrected in the HTML and PDF versions of the article.

\section{Erratum: Body-barrier surveillance by the epidermal $\gamma \delta$ TCRs}

Grzegorz Chodaczek, Veena Papanna, M Anna Zal \& Tomasz Zal

Nat. Immunol. 13, 272-282 (2012); published online 12 February 2012; corrected after print 4 April 2012

In the version of this article initially published, the designation for DETCs that lack a V $\gamma 5$ TCR is incorrect. The correct designation is ' $\mathrm{V} \gamma 5^{-}$.' Also, on page 273 , right column, second full paragraph, the designation for reporter mice in the first sentence is incorrect. The correct designation is 'IL-2p8-GFP'. The errors have been corrected in the HTML and PDF versions of the article.

\section{Corrigendum: The redox-sensitive cation channel TRPM2 modulates phagocyte ROS production and inflammation}

Anke Di, Xiao-Pei Gao, Feng Qian, Takeshi Kawamura, Jin Han, Claudie Hecquet, Richard D Ye, Stephen M Vogel \& Asrar B. Malik Nat. Immunol. 13, 29-34 (2012); published online 20 November 2011; corrected after print 3 February 2012

In the version of this article initially published, the description of the Trpm $2^{-1-}$ mice in the first paragraph of the Online Methods was incomplete. That section should read as follows: "Trpm $2^{-/-}$mice (obtained from B.A. Miller) were generated and originally provided by GlaxoSmithKline ${ }^{46}$. Another group has independently generated Trpm $2^{-1-}$ mice ${ }^{12}$; those were not used here." The new reference (46) is as follows: Knowles, H. et al. Transient receptor potential melastatin 2 (TRPM2) ion channel is required for innate immunity against Listeria monocytogenes. Proc. Natl. Acad. Sci. USA 108, 11578-11583 (2011). The error has been corrected in the HTML and PDF versions of the article. 